\title{
First triple-wavelength lidar observations of depolarization and extinction-to-backscatter ratios of Saharan dust
}

\author{
Moritz Haarig $^{1}$, Albert Ansmann ${ }^{1}$, Ronny Engelmann ${ }^{1}$, Holger Baars ${ }^{1}$, Carlos Toledano ${ }^{2}$, \\ Benjamin Torres $^{3}$, Dietrich Althausen ${ }^{1}$, Martin Radenz ${ }^{1}$, and Ulla Wandinger ${ }^{1}$ \\ ${ }^{1}$ Leibniz Institute for Tropospheric Research, Leipzig, Germany \\ ${ }^{2}$ Atmospheric Optics Group, University of Valladolid, Valladolid, Spain \\ ${ }^{3}$ Laboratoire d'Optique Atmosphérique, Université des Sciences et Technologies de Lille, \\ Villeneuve d'Ascq, France \\ Correspondence: Moritz Haarig (haarig@ tropos.de)
}

Received: 16 July 2021 - Discussion started: 30 July 2021

Revised: 25 October 2021 - Accepted: 16 November 2021 - Published: 11 January 2022

\begin{abstract}
Two layers of Saharan dust observed over Leipzig, Germany, in February and March 2021 were used to provide the first-ever lidar measurements of the dust lidar ratio (extinction-to-backscatter ratio) and linear depolarization ratio at all three classical lidar wavelengths $(355,532$ and $1064 \mathrm{~nm})$. The pure-dust conditions during the first event exhibit lidar ratios of $47 \pm 8,50 \pm 5$ and $69 \pm 14 \mathrm{sr}$ and particle linear depolarization ratios of $0.242 \pm 0.024,0.299 \pm 0.018$ and $0.206 \pm 0.010$ at wavelengths of 355,532 and $1064 \mathrm{~nm}$, respectively. The second, slightly polluted-dust case shows a similar spectral behavior of the lidar and depolarization ratio with values of the lidar ratio of $49 \pm 4,46 \pm 5$ and $57 \pm 9 \mathrm{sr}$ and the depolarization ratio of $0.174 \pm 0.041$, $0.298 \pm 0.016$ and $0.242 \pm 0.007$ at 355,532 and $1064 \mathrm{~nm}$, respectively. The results were compared with Aerosol Robotic Network (AERONET) version 3 (v3) inversion solutions and the Generalized Retrieval of Aerosol and Surface Properties (GRASP) at six and seven wavelengths. Both retrieval schemes make use of a spheroid shape model for mineral dust. The spectral slope of the lidar ratio from 532 to $1064 \mathrm{~nm}$ could be well reproduced by the AERONET and GRASP retrieval schemes. Higher lidar ratios in the UV were retrieved by AERONET and GRASP. The enhancement was probably caused by the influence of fine-mode pollution particles in the boundary layer which are included in the columnar photometer measurements. Significant differences between the measured and retrieved wavelength dependence of the particle linear depolarization ratio were found. The potential sources for these uncertainties are discussed.
\end{abstract}

\section{Introduction}

Triple-wavelength polarization Raman lidar observations of particle depolarization and extinction-to-backscatter ratios are of importance for several reasons. Many lidars (including ceilometers) are standard backscatter lidars and need trustworthy information about the particle extinction-tobackscatter ratio (lidar ratio) in the retrieval of backscatter and extinction profiles and aerosol optical depth (AOD). This is of special importance in the case of the spaceborne CALIPSO lidar (Cloud-Aerosol Lidar and Infrared
Pathfinder Satellite Observation) monitoring aerosol and clouds around the globe at 532 and $1064 \mathrm{~nm}$ (Omar et al., 2009; Kim et al., 2018). Besides CALIPSO, the CATS space lidar (Cloud-Aerosol Transport System, Yorks et al., 2016) will benefit from lidar ratio measurements at $1064 \mathrm{~nm}$, as well as possible future space missions operating a backscatter lidar at $1064 \mathrm{~nm}$.

Triple-wavelength lidar measurements are also important for aerosol typing efforts that make use of spectrally resolved intensive aerosol parameters such as the linear depolarization ratio and lidar ratio, as well as the extinction- 
and backscatter-related Ångström exponents for all climaterelevant aerosol types like marine aerosol, dust, smoke, volcanic ash and haze particles (Burton et al., 2012; Groß et al., 2013; Baars et al., 2017). In this respect, our measurements will contribute to these aerosol typing efforts by adding new information on dust lidar and depolarization ratios at $1064 \mathrm{~nm}$.

The most important aspect of triple-wavelength lidar observations of dust depolarization and lidar ratios is, however, that such measurements at all three classical aerosol lidar wavelengths (355, 532 and $1064 \mathrm{~nm}$ ) are required to improve optical models applied to simulate the optical properties of aerosol particles as a function of size distribution, shape characteristics and chemical composition. Especially in the case of mineral dust there is a strong request for those lidar observations to improve the applied particle shape parameterization. The optical properties of dust strongly depend on particle shape (depolarization ratio), size and mineralogy (lidar ratio). These data, presented here, will support the validation of shape models for the irregularly shaped dust particles.

Modeling of dust optical properties is especially challenging for the $180^{\circ}$ backscattering direction. Complex dust shape models were developed to improve the agreement between lidar observations and respective simulation results (Gasteiger et al., 2011; Kemppinen et al., 2015; Saito and Yang, 2021). The spheroidal shape model is widely used (Dubovik et al., 2006), e.g., in the analysis of Aerosol Robotic Network (AERONET, Holben et al., 1998) sun and sky radiometer measurements to obtain the inversion products which include the lidar ratio and the particle linear depolarization ratio at four wavelengths between 440 and $1020 \mathrm{~nm}$. The photometer retrieval products were compared with lidar measurements of desert dust (Tesche et al., 2009; Müller et al., 2010, 2012; Noh et al., 2017; Shin et al., 2018; Toledano et al., 2019), and discrepancies were found.

Triple-wavelength lidar observations of the depolarization ratio have been available since 2013 (Burton et al., 2015; Haarig et al., 2017). However, direct observations of the lidar ratio at all three lidar wavelengths are missing as was stated in Shin et al. (2018). Haarig et al. (2016) showed, for the first time, directly measured vertical profiles of the $1064 \mathrm{~nm}$ extinction coefficient. Since then, we have used the triple-wavelength Raman lidar approach to characterize cirrus (Haarig et al., 2016) and wildfire smoke (Haarig et al., 2018) in terms of backscatter, extinction, the lidar ratio and the depolarization ratio at 355,532 and $1064 \mathrm{~nm}$. Now, we present two case studies of pure-dust and polluted-dust outbreaks towards central Europe which occurred in February and March 2021. The first Saharan dust plume extended from the ground up to $8 \mathrm{~km}$ height and reached our station in Leipzig, Germany, in less than $2 \mathrm{~d}$ (around $36 \mathrm{~h}$ ) after emission. The fast transport process at great heights prevented mixing with anthropogenic pollution. The second dust outbreak occurred 1 week later. The dust spent more time over
Europe (3-4d of transport), and the dust plume mixed with European haze.

The article is structured as follows. After a short description of the lidar system and the additional, new option to measure extinction coefficients at $1064 \mathrm{~nm}$ in Sect. 2, the two observed dust cases are presented in Sect. 3. The discussion in Sect. 4 focuses on the Ångström exponents and the spectral dependence of the depolarization ratio and lidar ratio. We use the opportunity to compare our results with AERONET version 3 (v3) inversion results as well as with products obtained by applying the Generalized Retrieval of Aerosol and Surface Properties (GRASP) technique (Dubovik et al., 2014; Torres et al., 2017; Dubovik et al., 2021), available for the same dust event in February 2021.

\section{Instrumentation}

For the present study two lidars and an AERONET sun photometer at the Leibniz Institute for Tropospheric Research (TROPOS) in Leipzig $\left(51.35^{\circ} \mathrm{N}, 12.43^{\circ} \mathrm{E}\right)$, Germany, were used.

The multiwavelength polarization Raman lidar BERTHA (Backscatter Extinction lidar-Ratio Temperature Humidity profiling Apparatus, Haarig et al., 2017) provides the backscatter coefficient, extinction coefficient and depolarization ratio at 355,532 and $1064 \mathrm{~nm}(3+3+3$ configuration). However, it can not measure the depolarization ratio and the extinction coefficient at $1064 \mathrm{~nm}$ at the same time. A couple of minutes are necessary to switch the near-infrared (NIR) setup from depolarization to extinction measurements.

The radiometric or Rayleigh calibration of the signals was done in clear air, which at $1064 \mathrm{~nm}$ is a challenging task. At $1064 \mathrm{~nm}$ the elastic return signal from molecules is 81 times and 16 times smaller than for 355 and $532 \mathrm{~nm}$, respectively. The reference height for the $1064 \mathrm{~nm}$ signal was set some hundreds of meters above the dust layer top height for a sufficiently strong molecular signal. On 3 March 2021 (Sect. 3.2) a thick cirrus cloud was present, which could be used to check the Rayleigh calibration. A backscatter color ratio (1064/532) of 0.88 was observed, which is in line with observations by Vaughan et al. (2010), who reported values of $1.01 \pm 0.25$ in cirrus clouds. On 22 February 2021 (Sect. 3.1), the cirrus clouds were too thin to check the calibration.

The extinction coefficients at 355 and $532 \mathrm{~nm}$ were derived by using the vibrational-rotational Raman signals at 387 and $607 \mathrm{~nm}$, respectively. The rotational Raman technique (Whiteman, 2003a, b; Veselovskii et al., 2015; Haarig et al., 2016; Ortiz-Amezcua et al., 2020) was applied to provide measurements of the extinction coefficient at $1064 \mathrm{~nm}$. A detailed description of the rotational Raman technique implemented in BERTHA can be found in Haarig et al. (2016). The Raman channel is equipped with an interference filter centered at $1058 \mathrm{~nm}$ (Alluxa, Santa Rosa, CA, 
https://www.alluxa.com, last access: 8 October 2021). The transmission band is from 1053 to $1062 \mathrm{~nm}$ with a transmission $>90 \%$ in this wavelength range. The filter bandwidth of $9 \mathrm{~nm}$ restricts the $1058 \mathrm{~nm}$ Raman observations to nighttime hours. For the laser wavelength of $1064.14 \mathrm{~nm}$, the transmission is specified to be $0.005 \%$. For a better suppression of the transmitted radiation at $1064 \mathrm{~nm}$ two identical $1058 \mathrm{~nm}$ interference filters are used in front of the photomultiplier tube (photon counting, R3236 from Hamamatsu, Japan). However, some cross talk from the elastic signal at $1064 \mathrm{~nm}$ was still present in the Raman channel. The enhanced signal received from the liquid clouds on 22 February 2021 (Sect. 3.1) was used to estimate the cross-talk factor of $0.0175 \pm 0.0005$. For the further analysis, the elastic signal at $1064 \mathrm{~nm}$ multiplied by the cross-talk factor was subtracted from the Raman signal at $1058 \mathrm{~nm}$ to correct for the cross talk. In this simple approach, the cross talk is assumed to be temperature independent. The temperature-dependent transmission of the oxygen and nitrogen Raman lines varies from 0.729 to 0.793 between 288 and $208 \mathrm{~K}$, which was the maximum and minimum temperature observed in the troposphere on 22 February 2021. The rotational Raman signal at $1058 \mathrm{~nm}$ was corrected for the temperature dependence after the cross-talk correction. Within the dust layer, the correction led to around $3 \%$ higher extinction values. Detailed calculations of the temperature dependence of rotational Raman lidar signals can be found in Veselovskii et al. (2015).

In BERTHA, linearly polarized laser pulses are transmitted into the atmosphere, and the so-called co-polarized and cross-polarized signal components are measured. "Co" and "cross" denote the planes of polarization parallel and orthogonal to the plane of linear polarization of the transmitted laser pulses, respectively. In the case of spherical droplets and wet marine and small haze particles, the polarization state of the laser pulse radiation is preserved during the backscattering process, and the particle linear depolarization ratio (PLDR), computed from the ratio of the cross-polarized to the copolarized signal component, is close to zero. In the case of irregularly shaped dust particles, depolarization takes place during the backscattering event, and the PLDR values are close to 0.3 at $532 \mathrm{~nm}$ (Freudenthaler et al., 2009; Haarig et al., 2017). The calibration of the polarization-sensitive channels at all three wavelengths makes use of the so-called $\Delta 90^{\circ}$ method (Freudenthaler, 2016). The error estimation for the BERTHA system is described in Haarig et al. (2017).

The second lidar used in the present study is Polly $\mathrm{XT}$ (POrtabLe Lidar sYstem, neXT generation, Engelmann et al., 2016), which is usually used for ship-borne observations (Engelmann et al., 2021) within OCEANET - Atmosphere. It is a Raman polarization lidar, measuring the backscatter coefficient at 355, 532 and $1064 \mathrm{~nm}$; the extinction coefficient at 355 and $532 \mathrm{~nm}$ (vibrational-rotational Raman); and the depolarization ratio at 355 and $532 \mathrm{~nm}$. Additionally, near-range channels at 355, 387, 532 and $607 \mathrm{~nm}$ provide information at lower altitudes, and the dual-field-of- view polarization technique (Jimenez et al., 2020) is implemented to study liquid clouds. Polly ${ }^{\mathrm{XT}}$ was operated several meters apart from the BERTHA instrument.

A Cimel sun-sky photometer of AERONET (Holben et al., 1998) has been operated at Leipzig since 2000. Currently, only level 1.5 data are available for February and March 2021 , although the data already passed all quality criteria, including cloud screening and operational checks (Giles et al., 2019). Besides the standard AERONET data analysis procedure (Dubovik and King, 2000; Dubovik et al., 2006; Sinyuk et al., 2020), the related GRASP retrieval scheme was applied (Dubovik et al., 2014; Torres et al., 2017; Toledano et al., 2019; Dubovik et al., 2021). GRASP is based on an approach similar to the standard AERONET retrieval (Dubovik and King, 2000) but additionally uses optical information (AOD and radiances) at wavelengths of 380,500 and $1640 \mathrm{~nm}$. From both algorithms the column lidar ratios and depolarization ratios at several wavelengths were retrieved.

\section{Observations}

Two case studies of the triple-wavelength depolarization ratio and lidar ratio observations of Saharan dust from late winter 2021 will be shown. Pure-dust conditions were observed on 22-23 February 2021, while mixed pollution-dust conditions prevailed on 3 March 2021.

\subsection{First dust outbreak: 22-23 February 2021}

Huge amounts of mineral dust were emitted from western Saharan regions around and before 21 February 2021. The dust plumes were directly transported towards central Europe and reached Leipzig in less than $2 \mathrm{~d}$ (around $36 \mathrm{~h}$ ) after emission as shown by the HYSPLIT (Hybrid Single-Particle Lagrangian Integrated Trajectory, Stein et al., 2015) backward trajectories in Fig. 1b. More detailed source attributions indicate the Sahara as the main source region for the lofted layers (see Fig. 2). Below $3 \mathrm{~km}$ height, aerosol from continental Europe was probably mixed into the Saharan dust plumes. In the night of 22-23 February 2021, the dust plumes reached from the ground up to $8 \mathrm{~km}$ height. Saharan dust was transported towards central Europe continuously from the evening of 22 February until the morning of 26 February 2021. The whole dust event was studied using the continuous observation of the Polly ${ }^{\mathrm{XT}}$ lidar (https://polly.tropos.de/calendar/ location/1, last access: 20 October 2021; Baars et al., 2016). The transport pattern was similar to the dust outbreak in October 2001 described in Ansmann et al. (2003), which was measured by the entire EARLINET community (European Aerosol Research Lidar Network, now part of the Aerosol, Clouds and Trace gases Research Infrastructure, ACTRIS, Pappalardo et al., 2014).

The lidar measurements are presented in Fig. 1. The time-height plot (Fig. 1a) of the cross-polarized and rangecorrected signal at $532 \mathrm{~nm}$ provides an overview of the dust 

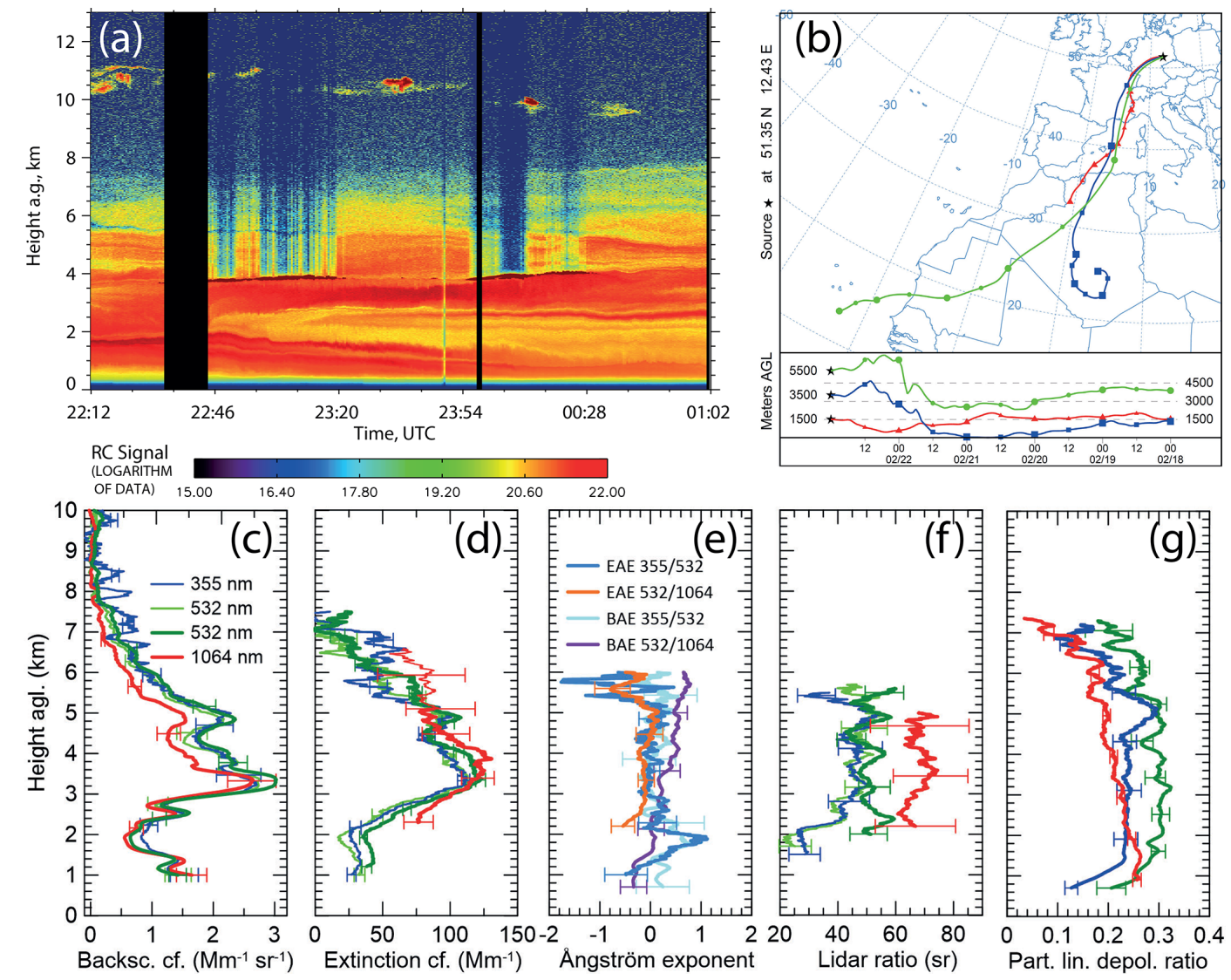

Figure 1. Saharan dust observations at Leipzig on 22-23 February 2021 at 22:12-01:02 UTC. (a) Time-height display of the 532 nm crosspolarized, range-corrected (RC) signal. (b) HYSPLIT back trajectory for 23 February 2021 at 00:00 UTC ( $<2 \mathrm{~d}$ from the Sahara to Leipzig; please note that the date format in this panel is month/day). (c) Particle backscatter coefficient (200 m vertical smoothing). (d) Particle extinction coefficient (950 m vertical smoothing, $2000 \mathrm{~m}(3290 \mathrm{~m}$ ) at $1064 \mathrm{~nm}$ below (above) $5 \mathrm{~km}$ ). (e) Extinction Ångström exponent (EAE) and backscatter Ångström exponent (BAE) for the given wavelengths pairs: 355/532 from Polly XT and 532/1064 from BERTHA. (f) Lidar ratio ( $950 \mathrm{~m}$ vertical smoothing, $2000 \mathrm{~m}$ at $1064 \mathrm{~nm}$ ). (g) Particle linear depolarization ratio (200 m vertical smoothing, $750 \mathrm{~m}$ at $355 \mathrm{~nm}$ ). BERTHA provided measurements at $532 \mathrm{~nm}$ (dark green) and $1064 \mathrm{~nm}$ (red), and Polly XT provided measurements at $355 \mathrm{~nm}$ (blue) and $532 \mathrm{~nm}$ (light green). All optical properties are shown for the period 22:45-01:02 UTC, except for the depolarization ratios shown at 22:12-22:32 UTC to be at the same time as the $1064 \mathrm{~nm}$ depolarization ratio measurement.

conditions observed with the BERTHA lidar system. During the first $20 \mathrm{~min}$ the system was in the configuration to measure the depolarization ratio at $1064 \mathrm{~nm}$. Then, the configuration was switched to permit measurements of the extinction coefficient at $1064 \mathrm{~nm}$ for the next $2 \mathrm{~h} 15 \mathrm{~min}$. Some clouds were forming in the humid dust layer at around $4 \mathrm{~km}$ height, indicated by strong backscatter signals (dark red) and the attenuation of laser radiation above the cloud layers. The cloud-containing profiles were excluded from the calculation of the dust optical properties but used for the estimation of the cross-talk correction. The signals at $355 \mathrm{~nm}$ of the BERTHA lidar were very weak during that night. In fact, neutral density filters in front of the UV channels were not adapted to the strongly reduced power of the UV laser. Therefore, the optical properties at $355 \mathrm{~nm}$ were taken from the nearby Polly ${ }^{\mathrm{XT}}$ measurements. Additionally, the optical properties at $532 \mathrm{~nm}$ measured with Polly ${ }^{\mathrm{XT}}$ are shown in
Fig. 1c-f. The profiles at $532 \mathrm{~nm}$ (green lines) from the different lidar observations agree well.

In the dust layer (main part at $3-5 \mathrm{~km}$ height, extending up to $8 \mathrm{~km}$ height), no wavelength dependence for the backscatter coefficient between 355 and $532 \mathrm{~nm}$ was found (backscatter Ångström exponent, $\mathrm{BAE}=0.040 \pm 0.524$ ). The backscatter coefficient at $1064 \mathrm{~nm}$ was around $80 \%$ of the value at $532 \mathrm{~nm}$ within the dust layer.

The extinction coefficient exceeded $100 \mathrm{Mm}^{-1}$ at around $3.5 \mathrm{~km}$ height at all three wavelengths. The total AOD was approximately 0.45 at $532 \mathrm{~nm}$ during that night. The extinction Ångström exponent (EAE, Fig. 1e) values were vertically constant within the dust layer and close to zero but slightly negative. The lidar ratio (Fig. 1f) derived in the strongest part of the dust layer (3-5 km height) increased with wavelength from $47 \pm 8 \mathrm{sr}$ at $355 \mathrm{~nm}$ to $50 \pm 5 \mathrm{sr}$ at $532 \mathrm{~nm}$ and $69 \pm 14 \mathrm{sr}$ at $1064 \mathrm{~nm}$. The particle linear de- 
polarization ratio (PLDR) at $532 \mathrm{~nm}$ of up to $0.30 \pm 0.02$ (3-5 km layer mean and systematic uncertainty) indicates pure-dust conditions (Freudenthaler et al., 2009). The PLDR decreases towards $355 \mathrm{~nm}(0.242 \pm 0.024)$ and $1064 \mathrm{~nm}$ $(0.206 \pm 0.010)$. In order to compare simultaneous observations of the PLDR, the values are reported for the first $20 \mathrm{~min}$ (22:12-22:32 UTC) when the $1064 \mathrm{~nm}$ channels measured the depolarization ratio, whereas all other intensive optical properties were measured from 22:45-01:02 UTC. The depolarization ratios for the later period were nearly the same $(0.256 \pm 0.025$ and $0.298 \pm 0.017$ at 355 and $532 \mathrm{~nm}$, respectively). A summary of the intensive optical properties measured in the night of 22-23 February 2021 can be found in Table 1.

The AERONET v3 inversion results for the lidar ratio and PLDR (five separate observations) performed on 23 February 2021 between 11:35 and 14:49 UTC will be compared with the lidar observations in Sect. 4. The AERONET measurement period is indicated in Fig. 2. The continuous observations of Polly ${ }^{\mathrm{XT}}$ and the source attribution for 23 February 2021 in Fig. 2 reveal that the same Saharan dust layer was present during the nighttime lidar measurements and the daytime AERONET observations. At lower heights, Europe is indicated besides the Sahara as a potential source region. The AERONET measurements from 22 February 2021 did not capture the Saharan dust event, which arrived at 19:00 UTC at Leipzig, with the first slices arriving already at 16:00 UTC.

\subsection{Second dust outbreak: 3 March 2021}

A second dust outbreak occurred 1 week later on 3 March 2021. The travel time was 3-4d from the Sahara to Leipzig via Spain and France as indicated by the HYSPLIT backward trajectories in Fig. 3b. On 3 March 2021, the dust plume arrived around 10:00 UTC over Leipzig with some cirrus clouds above. In the night, the dust plume reached its largest vertical extent. Some clouds were formed within the dust layer. On the morning of 4 March, around 06:00 UTC, precipitation started and washed out the dust. The development of the dust plume over Leipzig was studied using the continuous observation of PollyNET (https://polly.tropos.de/ calendar/location/1, Baars et al., 2016).

This time the BERTHA lidar was fully operational at all three wavelengths so that also the optical properties at $355 \mathrm{~nm}$ could be used. The lidar observations are shown in Fig. 3. The dust layer extended up to $5 \mathrm{~km}$ in the beginning; later on the dust plume descended down to $4 \mathrm{~km}$ height. During the first $20 \mathrm{~min}$, the lidar was configured to measure the depolarization ratio at $1064 \mathrm{~nm}(3+2+3$ configuration). The process of changing the interference and polarization filters was optimized so that $7 \mathrm{~min}$ later the extinction measurement at $1064 \mathrm{~nm}$ could be started $(3+3+2$ configuration). To avoid strong vertical smoothing of the extinction coefficient at $1064 \mathrm{~nm}$ as done in the previous case, signal profiles collected over 3 h 20 min (21:11-00:32 UTC) were av- eraged. The main dust layer extended from $1.5-4 \mathrm{~km}$ height and provided vertically homogeneous conditions for averaging. The profiles of the extinction coefficients and lidar ratios in Fig. $3 \mathrm{~d}$ and $\mathrm{f}$ are shown for a sliding average window length of $750 \mathrm{~m}$.

The AOD was 0.41 at $355 \mathrm{~nm}, 0.37$ at $532 \mathrm{~nm}$ and 0.34 at $1064 \mathrm{~nm}$. The lidar ratio in the center of the dust layer (2.0$3.5 \mathrm{~km}$ height $)$ at $1064 \mathrm{~nm}(57 \pm 9 \mathrm{sr})$ was slightly higher than at $532 \mathrm{~nm}(46 \pm 5 \mathrm{sr})$. The slight increase in the lidar ratio at $355 \mathrm{~nm}(49 \pm 4 \mathrm{sr})$ compared to $532 \mathrm{~nm}$ could be an indication for pollution mixed into the dust layer.

The depolarization ratios (Fig. 3g) were measured from 20:44-21:04 UTC. The dashed lines indicate the depolarization ratios at 355 and $532 \mathrm{~nm}$ (layer mean values $(2.0-3.5 \mathrm{~km}$ height) of $0.179 \pm 0.053$ and $0.264 \pm 0.0163$, respectively) measured at the same time as the other optical properties (21:11-00:32 UTC). The dust layer showed a larger vertical extent up to $5 \mathrm{~km}$ height and higher values of the PLDR at $532 \mathrm{~nm}(0.292 \pm 0.016)$ during the first shorter measurement period. Especially, the PLDR at $355 \mathrm{~nm}$ was significantly reduced $(0.174 \pm 0.041)$ compared to the previous case with pure-dust conditions. The longer transport over Europe obviously caused the weak mixing with anthropogenic pollution. A summary of the intensive optical properties measured on 3 March 2021 can be found in Table 1. Unfortunately, no AERONET observations could be used for comparison. The dust layer was accompanied by extended cirrus layers preventing sun photometer observations, and on the next day the precipitation event removed the dust.

\section{Discussion}

\subsection{Backscatter and extinction Ångström exponent}

The aerosol optical depth from the lidar measurement in the night of 22-23 February 2021 was $0.48 \pm 0.03$ at $355 \mathrm{~nm}$, $0.45 \pm 0.03$ at $532 \mathrm{~nm}$ and $0.45 \pm 0.03$ at $1064 \mathrm{~nm}$. Below the dust layer, the backscatter coefficient times a lidar ratio of $50 \mathrm{sr}$ was used to estimate the extinction coefficient. The uncertainty was estimated by varying the lidar ratio by $\pm 10 \mathrm{sr}$. Figure 2 shows a slight decrease in the dust plume height until the next morning where the AERONET observations were performed. Slightly lower AODs of 0.43 at $340 \mathrm{~nm}, 0.42$ at $500 \mathrm{~nm}$ and 0.36 at $1020 \mathrm{~nm}$ were measured by the photometer (AERONET, 2021).

The intensive optical properties such as the extinction Ångström exponent (EAE) are given in Table 1. The lidarderived EAE values for the three wavelengths are all negative but close to zero, ranging between $-0.005(355 / 532)$ and -0.098 (355/1064). Negative EAE (355/532) values down to -0.2 were observed for Saharan dust in Senegal (Veselovskii et al., 2016), where the EAE of Saharan dust accumulated in the interval of -0.2 to 0.2 .

The AERONET observations from the early morning of 23 February 2021 showed an Ångström exponent calculated 


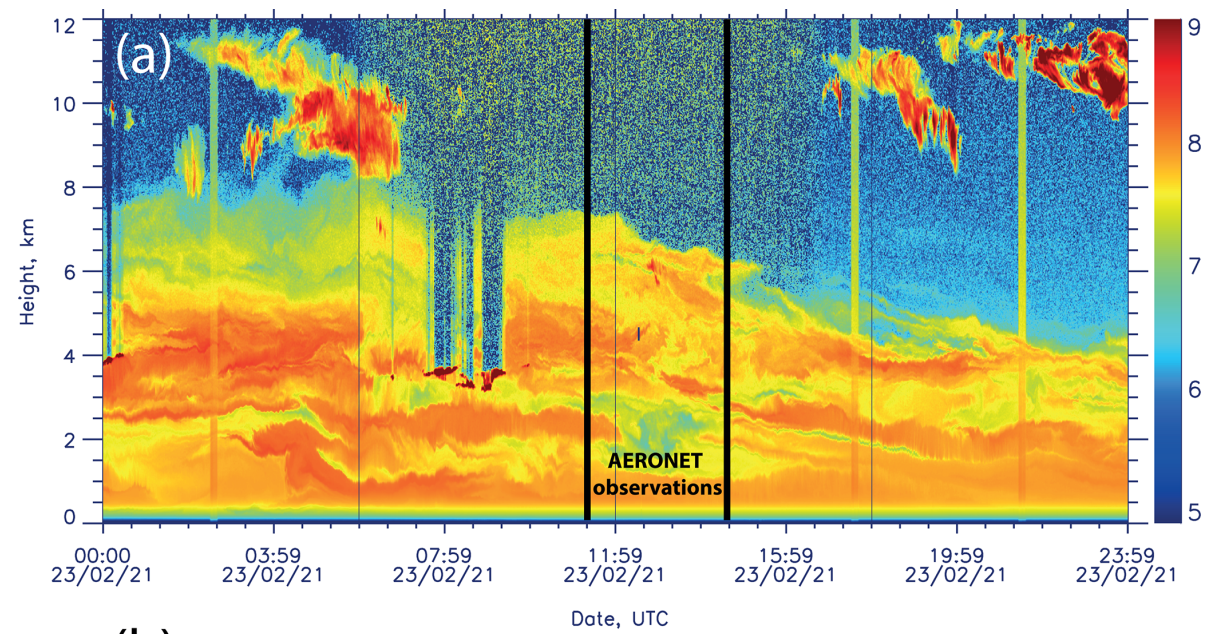

(b)

23/02/2021 Leipzig

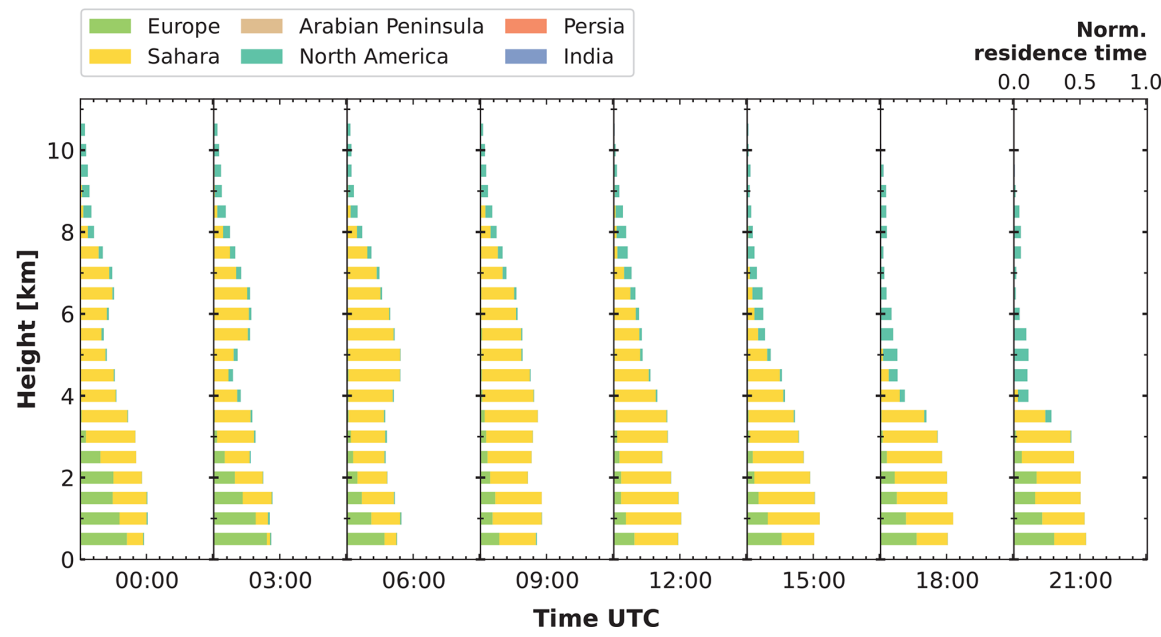

Figure 2. Development of the dust layer over Leipzig on 23 February 2021. (a) Cross-polarized, range-corrected signal at $532 \mathrm{~nm}$ measured with Polly XT (color scale in arbitrary units). The period of the five AERONET observations is marked by thick black vertical bars (please note that the date format in this panel is day/month/year). (b) Source attribution in $3 \mathrm{~h}$ intervals by using the method of Radenz et al. (2021). The normalized residence time of the air masses close to the ground (below $2 \mathrm{~km}$ height) within $10 \mathrm{~d}$ prior to the arrival over Leipzig at the indicated timestamps on 23 February 2021 is shown. The trajectory calculations are based on FLEXPART (FLEXible PARTicle dispersion model). The colors indicate different regions defined in Radenz et al. (2021). Here, the Sahara, continental Europe and North America are relevant.

from the AOD at 440 and $870 \mathrm{~nm}$ of $0.217 \pm 0.039$ and for the wavelengths $380 / 500$ of $0.124 \pm 0.073$ (AERONET, 2021). The greater and positive Angström exponent of the AERONET observations might be influenced by the small urban haze particles in the wintertime planetary boundary layer. The lidar data did not include these urban haze effects. Considering the whole column, AOD Ångström exponents from the lidar observations of $0.155 \pm 0.177$ (355/532), $0.008 \pm 0.021(532 / 1064)$ and $0.062 \pm 0.015(355 / 1064)$ were obtained. The AOD Ångström exponent in the UVVIS range agrees within the uncertainties, whereas the higher AOD at $1064 \mathrm{~nm}$ led to lower Ångström exponents from the lidar, probably due to an overestimation of the AOD at $1064 \mathrm{~nm}$ in the boundary layer.
The backscatter Ångström exponent (BAE) values are provided in Table 1. The backscatter coefficients at 355 and $532 \mathrm{~nm}$ were almost the same $(100 \pm 5 \%)$, whereas values at $1064 \mathrm{~nm}$ were lower (here $79 \%$ of the value at $532 \mathrm{~nm}$ ) as found in other observations of mineral dust (Veselovskii et al., 2016; Hofer et al., 2020). This behavior is expressed in the BAE (532/1064) of 0.35 and that at Barbados of 0.47 . Liu et al. (2008) reported CALIPSO observations of the backscatter color ratios (1064/532) of 0.72-0.75 in Saharan dust. This translates to an average BAE of 0.44 , which is comparable to the value observed in the Saharan air layer at Barbados. 
Table 1. Intensive optical properties of Saharan dust observed at Leipzig on 22-23 February (pure-dust case) and 3 March 2021 (slightly polluted-dust case). For comparison, the optical properties of long-range-transported Saharan dust at Barbados as observed during the SALTRACE campaign are provided; the PLDR values during SALTRACE are taken from Haarig et al. (2017). The PLDR values of the Leipzig cases are reported for the triple-wavelength depolarization setup of the measurement (first 20 min), whereas the other properties are reported for the triple-wavelength extinction measurement. SAL - Saharan air layer, PLDR - particle linear depolarization ratio, EAE extinction Ångström exponent, BAE - backscatter Ångström exponent.

\begin{tabular}{lrrrr}
\hline & Wavelength (nm) & $22-23$ Feb 2021 & 3 Mar 2021 & SALTRACE \\
\hline Height range & & $3-5 \mathrm{~km}$ & $2-3.5 \mathrm{~km}$ & SAL \\
\hline \multirow{2}{*}{ Lidar ratio } & 355 & $47 \pm 8 \mathrm{sr}$ & $49 \pm 4 \mathrm{sr}$ & $59 \pm 16 \mathrm{sr}$ \\
& 532 & $50 \pm 5 \mathrm{sr}$ & $46 \pm 5 \mathrm{sr}$ & $57 \pm 8 \mathrm{sr}$ \\
Ratio of lidar ratios & 1064 & $69 \pm 14 \mathrm{sr}$ & $57 \pm 9 \mathrm{sr}$ & $67 \pm 15 \mathrm{sr}^{\mathrm{a}}$ \\
\hline & $355 / 532$ & $0.94 \pm 0.19$ & $1.07 \pm 0.14$ & $1.04 \pm 0.30$ \\
PLDR & $1064 / 532$ & $1.38 \pm 0.31$ & $1.24 \pm 0.24$ & $1.31 \pm 0.32^{\mathrm{b}}$ \\
\hline \multirow{2}{*}{ Ratio of the PLDR } & 355 & $0.242 \pm 0.024$ & $0.174 \pm 0.041$ & $0.252 \pm 0.030$ \\
& 532 & $0.299 \pm 0.018$ & $0.292 \pm 0.016$ & $0.280 \pm 0.020$ \\
& 1064 & $0.206 \pm 0.010$ & $0.242 \pm 0.007$ & $0.225 \pm 0.022$ \\
\hline \multirow{2}{*}{ EAE } & $355 / 532$ & $0.81 \pm 0.09$ & $0.60 \pm 0.14$ & $0.90 \pm 0.12$ \\
& $1064 / 532$ & $0.69 \pm 0.05$ & $0.83 \pm 0.05$ & $0.80 \pm 0.10$ \\
\hline & $355 / 532$ & $-0.005 \pm 0.186^{\mathrm{c}}$ & $0.332 \pm 0.051$ & $0.103 \pm 0.254$ \\
BAE & $532 / 1064$ & $-0.083 \pm 0.213$ & $0.008 \pm 0.079$ & - \\
& $355 / 1064$ & $-0.098 \pm 0.139$ & $0.128 \pm 0.067$ & - \\
\hline
\end{tabular}

${ }^{a}$ Estimated using lidar and AERONET. ${ }^{b}$ Here the lidar ratio at $532 \mathrm{~nm}(51 \mathrm{sr})$ of the same day (20 June 2014) was used.

${ }^{c}$ Polly ${ }^{\mathrm{XT}}$ data at 355 and $532 \mathrm{~nm}$ were used.

\subsection{Spectral dependence of the lidar ratio}

The discussion of the spectral behavior of the lidar ratio of Saharan dust is based on the two presented case studies from Leipzig and observations at Barbados during the Saharan Aerosol Long-range Transport and Aerosol-CloudInteraction Experiment (SALTRACE, Weinzierl et al., 2017). The BERTHA lidar system at Barbados $\left(13^{\circ} \mathrm{N}\right.$, $59^{\circ} \mathrm{W}$ ) measured the Saharan dust after long-range transport over $5000-8000 \mathrm{~km}$ across the Atlantic Ocean in three intensive campaigns in 2013 and 2014 (Haarig et al., 2017). The statistics of the lidar ratio at 355 and $532 \mathrm{~nm}$ and the Ångström exponents based on 22 SALTRACE measurement cases are reported in the present publication for the first time (Table 1).

During the SALTRACE campaigns, the rotational Raman technique applied to measure the extinction at $1064 \mathrm{~nm}$ was not implemented in the BERTHA lidar. However, the lidar ratio at $1064 \mathrm{~nm}$ could be estimated for one intense dust event with very homogeneous dust conditions observed on 20 June 2014. Here, the column-integrated backscatter coefficient at $1064 \mathrm{~nm}$ in the dust layer after sunset and the AOD at $1020 \mathrm{~nm}$ (from AERONET observations) before sunset were used as described in Mamouri and Ansmann (2017).
An AOD contribution of 0.035 for marine aerosol below the dust layer was subtracted to obtain the pure-dust value for the lidar ratio estimate. This method led to a dust lidar ratio of $67 \pm 15 \mathrm{sr}$ at $1064 \mathrm{~nm}$.

The spectral dependence of the lidar ratio of Saharan dust is shown in Fig. 4a. The lidar ratio does not change significantly in the wavelength range of 355 to $532 \mathrm{~nm}$. In the case of Saharan dust, this behavior was observed in numerous studies (e.g., Tesche et al., 2011; Groß et al., 2015). Some studies, however, point to higher values in the UV (Mattis et al., 2002). Veselovskii et al. (2020) observed cases with the same lidar ratio at 355 and $532 \mathrm{~nm}$ and cases with higher lidar ratios at $355 \mathrm{~nm}$. The ratio of lidar ratios for 355 and $532 \mathrm{~nm}$ is an indicator of the imaginary refractive index enhancement in the UV depending on the mineralogical composition of the dust particles (Veselovskii et al., 2020).

The present study indicates an increase of the lidar ratio from 532 to $1064 \mathrm{~nm}$. As mentioned, the reason is the lower particle backscatter coefficient $\beta$ at $1064 \mathrm{~nm}$ compared to the one at $532 \mathrm{~nm}$ so that the backscatter Angström exponent BAE, defined as $\mathrm{BAE}_{\lambda_{i}, \lambda_{j}}=\ln \left(\beta_{i} / \beta_{j}\right) / \ln \left(\lambda_{j} / \lambda_{i}\right)$ in the spectral range from wavelength $\lambda_{i}$ to $\lambda_{j}$, is positive. The extinction coefficient $\alpha$ usually does not show a significant wavelength dependence so that the respective extinction 

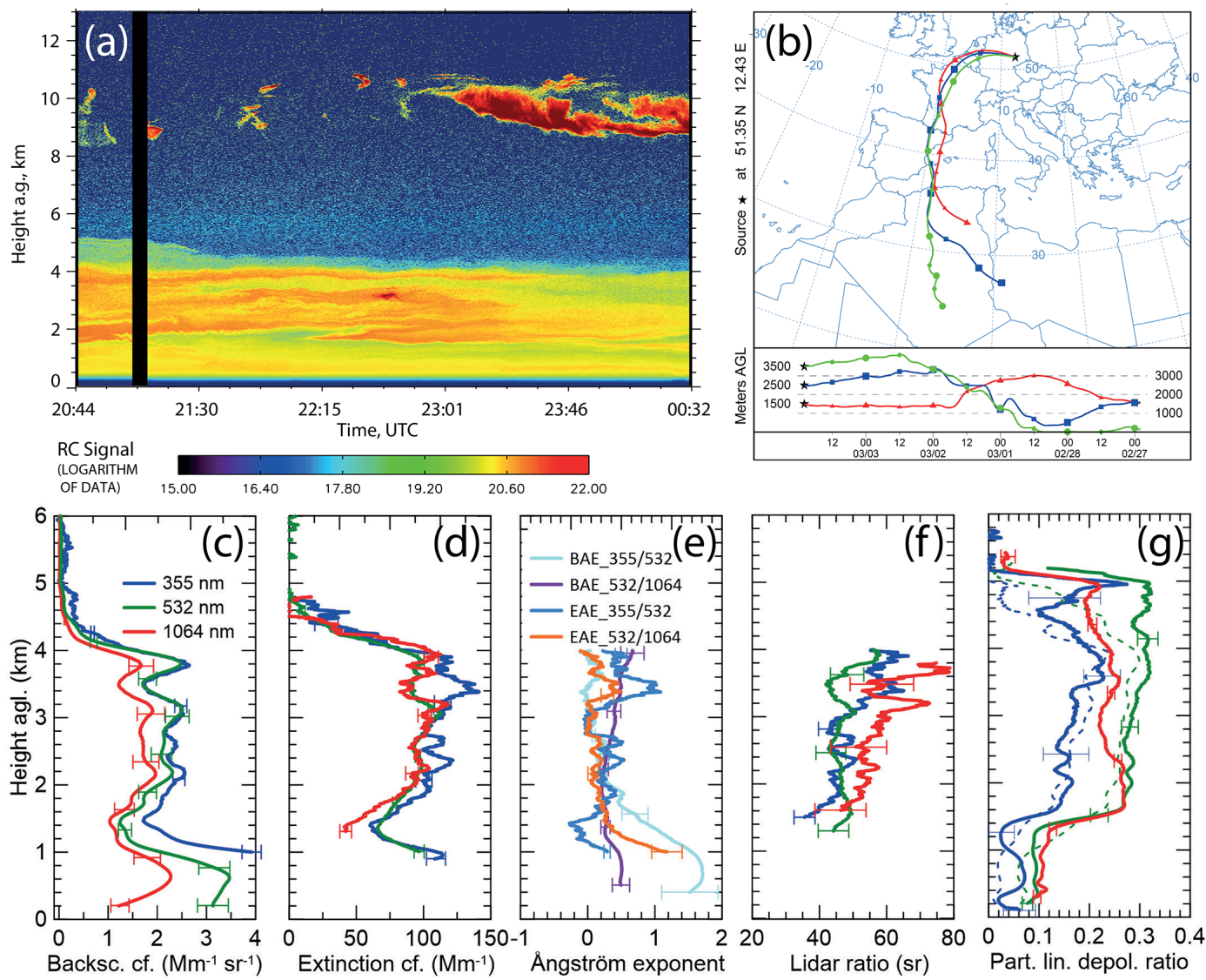

Figure 3. Same as Fig. 1, except for 3-4 March 2021 at 20:44-00:32 UTC. (a) Time-height display of the $532 \mathrm{~nm}$ cross-polarized, rangecorrected (RC) signal. (b) HYSPLIT back trajectory for 3 March 2021 at 22:00 UTC (please note that the date format in this panel is month/day). (c) Particle backscatter coefficient ( $200 \mathrm{~m}$ vertical smoothing). (d) Particle extinction coefficient ( $750 \mathrm{~m}$ vertical smoothing). (e) Extinction Ångström exponent (EAE, $750 \mathrm{~m}$ vertical smoothing) and backscatter Ångström exponent (BAE, $200 \mathrm{~m}$ vertical smoothing) for the given wavelengths pairs. (f) Lidar ratio (750 m vertical smoothing). (g) Particle linear depolarization ratio (PLDR, $200 \mathrm{~m}$ vertical smoothing). All shown optical properties are the mean profiles from 21:11-00:32 UTC, except the thick lines of the PLDR (20:44-21:04 UTC). The dashed lines of the PLDR at 355 and $532 \mathrm{~nm}$ belong to the main measurement at 21:11-00:32 UTC, where the dust layer height decreased.

Ångström exponent EAE is close to zero as shown in Figs. 1e and 3e. According to Ansmann et al. (2002), the lidar-ratiorelated Ångström exponent SAE, given by

$\mathrm{SAE}=\mathrm{EAE}-\mathrm{BAE}$,

is then negative. This relationship (Eq. 1) holds within the uncertainties for the intensive optical properties provided in Table 1.

The ratios of the lidar ratios given in Table 1 quantify the increase of the lidar ratio from 532 to $1064 \mathrm{~nm}$. We found around $24 \%-38 \%$ higher values for the lidar ratio at $1064 \mathrm{~nm}$ compared to $532 \mathrm{~nm}$. A similar increase (27\%$34 \%$ ) in the lidar ratio from 532 to $1064 \mathrm{~nm}$ was observed from three early CALIPSO measurements of Saharan dust transported from Africa across the Atlantic (Liu et al., 2008).

Combined sun photometer and lidar observations during the Saharan Mineral Dust Experiment (SAMUM) in Morocco led to the conclusion that the lidar ratio is almost in- dependent of wavelength with values of $55 \pm 5,56 \pm 5$ and $59 \pm 7 \mathrm{sr}$ at 355,532 and $1064 \mathrm{~nm}$, respectively (Tesche et al., 2009). The authors used the extinction Angström exponent (for the 500-1020 nm wavelength range) from sun photometer observations to transfer the extinction profile from 532 to $1064 \mathrm{~nm}$ and calculate the lidar ratio at $1064 \mathrm{~nm}$ using the corresponding backscatter profile in addition. In contrast to those measurements for freshly emitted dust close to its source, we found lidar ratio values of $47 \pm 8,50 \pm 5$ and $69 \pm 14 \mathrm{sr}$ for the three wavelengths after a dust transport of less than $2 \mathrm{~d}$.

The spectral dependence of the lidar ratio measured with lidar and retrieved from the AERONET observations is compared in Fig. 4b. The AERONET database (AERONET, 2021) provides AOD values at $440,675,870$ and $1020 \mathrm{~nm}$ together with further products such as the lidar ratio and linear depolarization ratio. The lidar ratio and particle linear depolarization ratio are retrieved by means of the AERONET v3 

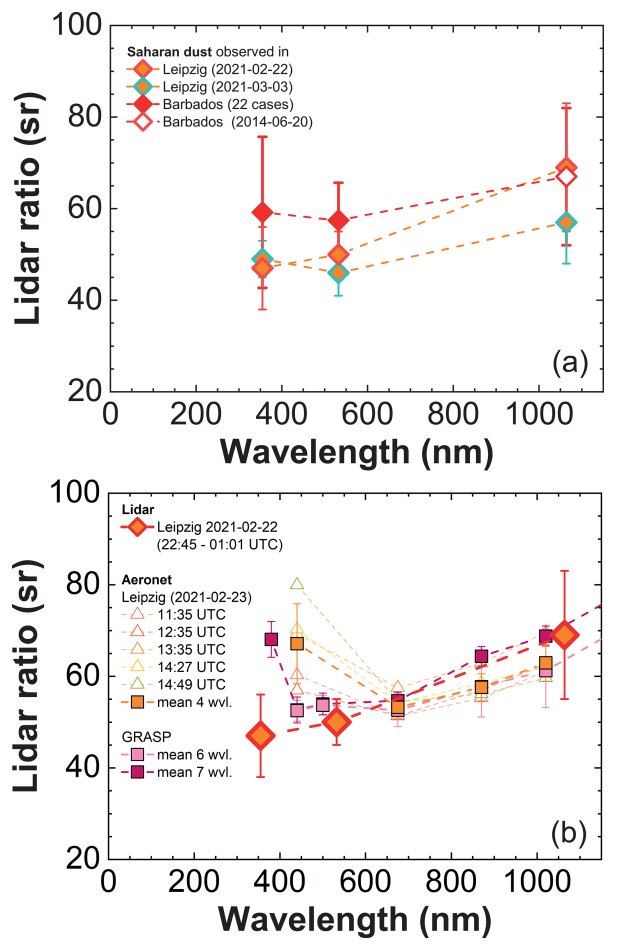

Figure 4. (a) Spectral dependence of the lidar ratio of Saharan dust observed at Leipzig and Barbados (during SALTRACE). The lidar ratio at $1064 \mathrm{~nm}$ during SALTRACE (open diamond) was estimated on 20 June 2014 combining AERONET AOD and lidar observations (see text for explanations and Mamouri and Ansmann, 2017; please note that the date format is year-month-day). (b) Spectral dependence of the lidar ratio of Saharan dust observed in the night of 22-23 February 2021 compared with AERONET v3 inversion solutions for the lidar ratio on 23 February 2021. The results of the five photometer scans (open triangles) at indicated times are shown together with the mean of the four-wavelength retrieval (orange squares, standard retrieval) and the six- and seven-wavelength retrieval (pink and purple squares, GRASP method). The GRASP retrieval at $1640 \mathrm{~nm}$ (not shown) leads to lidar ratios of $94 \pm 8$ (using six wavelengths) and $101 \pm 4 \mathrm{sr}$ (using seven wavelengths).

inversion algorithm (Dubovik and King, 2000; Giles et al., 2019; Sinyuk et al., 2020), which assumes a spheroidal dust particle shape (Dubovik et al., 2006). Additionally to the standard four wavelengths, the inversion was performed using the GRASP algorithm at six wavelengths (plus 500 and $1640 \mathrm{~nm}$ ) and seven wavelengths (plus $380 \mathrm{~nm}$, Dubovik et al., 2014; Torres et al., 2017; Dubovik et al., 2021). For the mean values the data were filtered in the way that the residual is $<10 \%$ of the inversion retrieval. Since radiance measurements were included in the GRASP data analysis, the refractive index and the sphericity are not preset and are retrieved following the same strategy as AERONET but with the extra information provided by the use of more wavelengths. A comparison of the lidar observations with the respective AERONET v3 inversion products was only possible on $22-$ 23 February 2021.
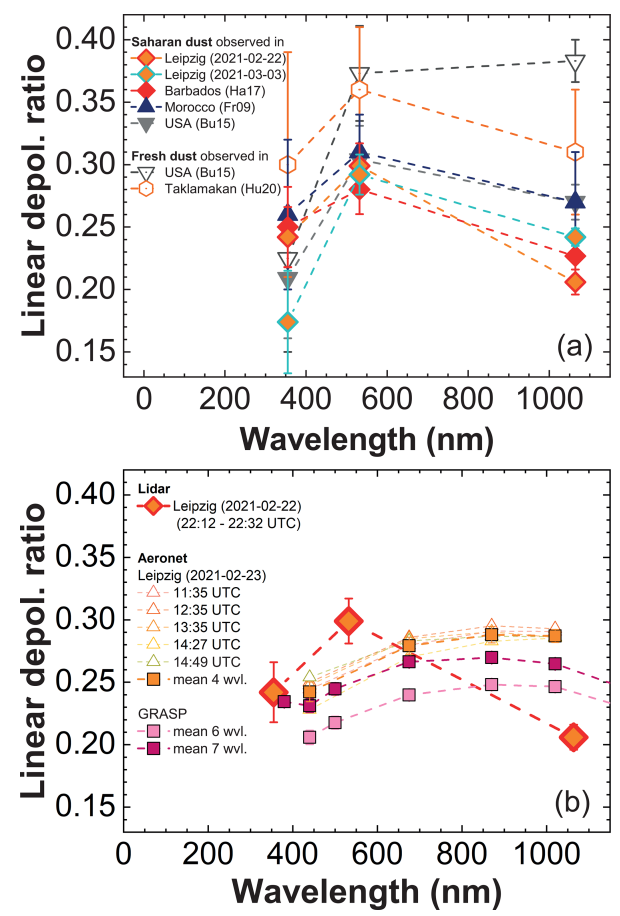

Figure 5. (a) Spectral dependence of the particle linear depolarization ratio (PLDR) of desert dust. The Leipzig observations are compared with triple-wavelength depolarization ratio measurements of Saharan dust and fresh dust available in the literature (Ha17 Haarig et al., 2017; Fr09 - Freudenthaler et al., 2009; Bu15 Burton et al., 2015; and $\mathrm{Hu} 20$ - Hu et al., 2020; please note that the date format is year-month-day). (b) Spectral dependence of the PLDR of Saharan dust observed in the night of 22-23 February 2021 compared with AERONET v3 inversion solutions for the PLDR on 23 February 2021. The results of the five photometer scans at indicated times are shown together with the mean of the four-wavelength retrieval (orange squares, standard retrieval) and the six- and seven-wavelength retrieval (pink and purple squares, GRASP method). The GRASP retrieval at $1640 \mathrm{~nm}$ (not shown) leads to PLDR values of $0.184 \pm 0.007$ (using six wavelengths) and $0.192 \pm 0.008$ (using seven wavelengths).

The spectral slope of the lidar ratio is well reproduced by the AERONET observations for the spectral range from 675 to $1020 \mathrm{~nm}$. The seven-wavelength mean values show exactly the same spectral slope as obtained by the lidar observations. The retrieved lidar ratios at $440 \mathrm{~nm}$ using the standard AERONET algorithm indicate higher values of the lidar ratio in the UV range. The GRASP retrieval at $440 \mathrm{~nm}$ shows a much better agreement with the lidar observations. The increase of the lidar ratio at $380 \mathrm{~nm}$ (seven-wavelength retrieval) points again to higher values of the lidar ratio in the UV range. The enhanced lidar ratios in the UV retrieved by AERONET were already discussed by Shin et al. (2018): the increase of the imaginary part of the refractive index at $440 \mathrm{~nm}$ compared to $675 \mathrm{~nm}$ is too strong in the AERONET 
inversion procedure, resulting in lidar ratios that are too high at $440 \mathrm{~nm}$.

However, in the present case the explanation might be simpler. The sun photometer measures columnar values, whereas the profile measurement of lidar permits focusing on the dust layer only. The fine-mode aerosol pollution of the wintertime boundary layer at Leipzig can significantly influence the AERONET lidar ratio products, especially at the shorter wavelengths of 440 and $380 \mathrm{~nm}$. Therefore, the columnar lidar ratio should increase towards the UV.

As mentioned, the refractive index depends on the mineralogical composition of dust particles, and this changes for different dust source regions. Schuster et al. (2012) investigated the variation of the lidar ratio obtained from AERONET observations for different deserts around the earth and found significant differences. The highest lidar ratios were found for the western Sahara, with lower values for Asian deserts. The global coverage of AERONET sun photometers is a big advantage. However, the retrievals should be checked against Raman or high-spectral-resolution lidar (HSRL) observations as has been started by Shin et al. (2018), ideally in a desert, where no other aerosol type contributes to the columnar values. The present study indicates a good agreement of the lidar ratio in the spectral range of 675 to $1020 \mathrm{~nm}$.

\subsection{Spectral dependence of the depolarization ratio}

The spectral dependence of the particle linear depolarization ratio of Saharan dust is shown in Fig. 5a. The results of the two presented case studies are in the context of previous triple-wavelength depolarization ratio observations. The observations of Saharan dust close to its source in Morocco (Freudenthaler et al., 2009) and after long-range transport towards Barbados (Haarig et al., 2017) and North America (Burton et al., 2015) show a consistent spectral slope. The PLDR increases in the wavelength range from 355 to $532 \mathrm{~nm}$ and then decreases again towards the wavelength of $1064 \mathrm{~nm}$.

Table 1 provides the values for the two presented case studies at Leipzig and the SALTRACE observations. The table includes the ratio of the PLDR for the wavelength pairs of 355 and $532 \mathrm{~nm}$ and of 1064 and $532 \mathrm{~nm}$. The depolarization ratio at $355 \mathrm{~nm}$ was very low on 3 March 2021 $(0.174 \pm 0.041)$ and probably reflects the impact of aerosol pollution mixed into the dust layers. The small and spherical pollution particles affect the backscattering at shorter wavelengths more effectively than at longer wavelengths. For pure Saharan dust (22-23 February 2021, Barbados and Morocco), the PLDR at $355 \mathrm{~nm}$ reached around $80 \%-90 \%$ of the value at $532 \mathrm{~nm}$. The PLDR at $1064 \mathrm{~nm}$ depends on the amount of rather large dust particles in the observed layer and thus is very sensitive to the travel duration (and the corresponding removal of large particles). The decrease of the PLDR with wavelength in the range from 532 to $1064 \mathrm{~nm}$ is expressed by PLDR ratios of $0.69-0.83$ for Saharan dust after long-range transport (Table 1).

The spectral slope of the PLDR is not a unique feature of Saharan dust. Hu et al. (2020) observed the same spectral dependence but with generally higher values for dust from the Taklamakan Desert in western China. Observations were performed very close to the main dust sources and thus with an enhanced fraction of very large dust particles. The same behavior was found for locally emitted dust in the southwest of the United States (Burton et al., 2015). The large dust particles of the freshly emitted dust were still present in the air during the lidar observations and produced significantly higher depolarization ratios of $0.38 \pm 0.01$ at $1064 \mathrm{~nm}$.

The spectral dependence of the PLDR in Fig. 5b derived from the sun and sky photometer observations is very different from the respective lidar observations of the PLDR spectral behavior. The lidar measurements of desert dust generally show a pronounced maximum of the depolarization ratio in the visible wavelength range. This is not visible in the AERONET spectra. Using the GRASP method (including the use of optical data measured at $1640 \mathrm{~nm}$, not shown in the figure) leads to a decrease of the PLDR with wavelength, starting already at $1020 \mathrm{~nm}$. However, the PLDR in the NIR is still overestimated for the presented case, in which a PLDR of $0.206 \pm 0.010$ at $1064 \mathrm{~nm}$ was measured. Compared to previous observations of the PLDR at $1064 \mathrm{~nm}$ (Fig. 5), the value is quite low. The six- and seven-wavelength GRASP retrievals lead to a better agreement in the NIR but underestimates the depolarization ratio at shorter wavelengths. Previous comparisons of lidar-measured and AERONET-retrieved depolarization ratios pointed out that the spheroidal model used for the AERONET inversions fails to predict the spectral slope of the PLDR (Noh et al., 2017; Shin et al., 2018). Only Toledano et al. (2019) were able to obtain the spectral slope as observed with polarization lidar systems by using the six-wavelength sun photometer retrieval for Saharan dust observations on Barbados during SALTRACE. In their study, the PLDR increases from $0.277 \pm 0.040$ at $440 \mathrm{~nm}$ to $0.282 \pm 0.031$ at $675 \mathrm{~nm}$ and then decreases again to $0.259 \pm 0.030$ at $1020 \mathrm{~nm}$. A further decrease was retrieved for the wavelength of $1640 \mathrm{~nm}(0.191 \pm 0.028)$.

Again, the boundary-layer fine-mode pollution (over Leipzig) influenced the AERONET retrievals and may lead to smaller AERONET depolarization ratio values than observed with lidar in the lofted dust layer. However, the significant discrepancies between the AERONET and the lidar observations in the $532-1064 \mathrm{~nm}$ spectral range remain an unsolved issue and seem to be related to the used spheroidal shape model in the AERONET and GRASP retrieval schemes. 


\section{Conclusions}

We presented, for the first time, measurements of the dust lidar ratio at the main aerosol lidar wavelengths of 355 , 532 and $1064 \mathrm{~nm}$. Together with the depolarization ratio at these wavelengths, we demonstrated the unique potential of a triple-wavelength polarization Raman lidar to permit socalled $3+3+3$ profiling (three backscatter coefficients, three extinction coefficients and three depolarization ratios). Two case studies of Saharan dust over central Europe were presented, one for pure-dust conditions and another case with slightly polluted dust. The measurement of the depolarization ratio and lidar ratio at three wavelengths from 355 to $1064 \mathrm{~nm}$ provides an improved, more complete set of constraints in modeling efforts to develop a realistic dust particle shape model. A better assessment of the absorption properties which are linked to the mineralogical composition of the dust particles may be possible by considering the spectral information of the lidar ratio at 355, 532 and $1064 \mathrm{~nm}$. Nevertheless, realistic assumptions of the imaginary part of the refractive index are required. Good measurements of the refractive index are important to allow for an accurate computation of the spectral slope of the lidar ratio in the wavelength range from 355 to $1064 \mathrm{~nm}$.

To derive the extinction coefficient at $1064 \mathrm{~nm}$ from backscatter lidars and ceilometers, realistic estimates of the lidar ratio at this wavelength are necessary. We presented the first direct measurements of the lidar ratio at $1064 \mathrm{~nm}$ for Saharan dust. It would be desirable, in this context, to perform such triple-wavelength lidar measurements in very different desert regions of the world. Middle Eastern and central Asian dust show, e.g., lower lidar ratios, especially at $532 \mathrm{~nm}$, as presented here (Hofer et al., 2020). We found lidar ratios of $47 \pm 8,50 \pm 5$ and $69 \pm 14 \mathrm{sr}$ at 355,532 and $1064 \mathrm{~nm}$, respectively, for pure-dust conditions and respective lidar ratios of $49 \pm 4,46 \pm 5$ and $57 \pm 9$ sr for slightly polluted dust. In central Asia, pure-dust lidar ratios were on average $43 \pm 3$ and $39 \pm 4 \mathrm{sr}$ at 355 and $532 \mathrm{~nm}$, respectively (Hofer et al., 2020).

The lidar ratios at 532 and $1064 \mathrm{~nm}$ are important input parameters for the CALIPSO lidar data analysis to derive the respective extinction coefficients at these two wavelengths (Omar et al., 2009). In version 4 of the retrieval algorithm, lidar ratios of $44 \pm 9 \mathrm{sr}$ at $532 \mathrm{~nm}$ and $44 \pm 13 \mathrm{sr}$ at $1064 \mathrm{~nm}$ are used for the aerosol type of pure dust (Kim et al., 2018). Based on our results, we would suggest to use a higher value at $1064 \mathrm{~nm}$ compared to $532 \mathrm{~nm}$.

The comparison with AERONET v3 inversion products revealed that the spectral dependence of the PLDR was not matched by the AERONET results. The GRASP computations based on the optical information (AOD and radiances) measured at six and seven wavelengths improved the agreement but led to overall lower values. In contrast to lidar systems which only operate at a $180^{\circ}$ backscatter angle, this angle is not accessible for the photometer. Therefore, the pho- tometer retrievals are not optimized for this special angle. Joint inversions of the lidar and photometer data as done in Lopatin et al. (2021) would be desirable.

The lidar measurements could confirm the spectral slope of the lidar ratio from the visible spectrum towards the NIR retrieved by the AERONET and GRASP data analysis. The fine-mode pollution aerosol in the boundary layer led to higher lidar ratios in the UV from the columnar photometer measurements compared to the Saharan dust observations with lidar.

We may conclude that an appropriate particle shape model for the non-spherical dust particles is still missing. The spheroidal shape model (Dubovik et al., 2006) has proven to be useful to derive volume and surface area concentrations from sky radiance and AOD observations at several wavelengths even for non-spherical dust particles. However, this shape model is not able to reproduce the spectral slope of the particle linear depolarization ratio with a maximum at $532 \mathrm{~nm}$ measured with lidar at the $180^{\circ}$ backscatter direction. Complex particle shape models (Gasteiger et al., 2011; Kemppinen et al., 2015; Saito et al., 2021) are computationally expensive. Nevertheless, they may lead to a more realistic representation of the irregularly shaped dust particles for the $180^{\circ}$ backscatter direction in the models.

As a final remark, it would be helpful - and a good addition to field observations - if laboratory measurements of the depolarization and lidar ratios at all three wavelengths (in the $180^{\circ}$ backscatter direction) could be realized for well-defined size fractions of real dust particles with real irregular-shape characteristics. An effort was already started by Miffre et al. (2016).

Data availability. The BERTHA lidar data can be obtained upon request from Moritz Haarig (haarig@tropos.de). The Polly XT data are available in the PollyNET database (https://polly.tropos.de/) (PollyNET, 2021). The AERONET data are available via the AERONET web page (https://aeronet.gsfc.nasa.gov/) under the site "Leipzig" (AERONET, 2021).

Author contributions. MH performed the lidar measurements, analyzed the data and wrote the manuscript. AA provided advice and valuable comments on the manuscript. RE supported the rotational Raman measurements. HB provided the Polly ${ }^{X T}$ results. DA provided technical support for the BERTHA lidar system. CT and BT provided the six- and seven-wavelength GRASP retrieval. MR did the source appointment analysis. UW provided comments on light scattering.

Competing interests. The contact author has declared that neither they nor their co-authors have any competing interests. 
Disclaimer. Publisher's note: Copernicus Publications remains neutral with regard to jurisdictional claims in published maps and institutional affiliations.

Acknowledgements. The authors thank Mark Vaughan, Oleg Dubovik and the anonymous reviewer for their helpful comments and suggestions improving the quality of the paper.

Financial support. The publication of this article was funded by the Open Access Fund of the Leibniz Association.

Review statement. This paper was edited by Farahnaz Khosrawi and reviewed by Mark Vaughan, Oleg Dubovik, and one anonymous referee.

\section{References}

AERONET: Aerosol Robotic Network aerosol database, available at: https://aeronet.gsfc.nasa.gov/, last access: 23 June 2021.

Ansmann, A., Wagner, F., Müller, D., Althausen, D., Herber, A., von Hoyningen-Huene, W., and Wandinger, U.: European pollution outbreaks during ACE 2: Optical particle properties inferred from multiwavelength lidar and star-Sun photometry, J. Geophys. Res.-Atmos., 107, AAC 8-1-AAC 8-14, https://doi.org/10.1029/2001JD001109, 2002.

Ansmann, A., Bösenberg, J., Chaikovsky, A., Comerón, A., Eckhardt, S., Eixmann, R., Freudenthaler, V., Ginoux, P., Komguem, L., Linné, H., Márquez, M. A. L., Matthias, V., Mattis, I., Mitev, V., Müller, D., Music, S., Nickovic, S., Pelon, J., Sauvage, L., Sobolewsky, P., Srivastava, M. K., Stohl, A., Torres, O., Vaughan, G., Wandinger, U., and Wiegner, M.: Long-range transport of Saharan dust to northern Europe: The 11-16 October 2001 outbreak observed with EARLINET, J. Geophys. Res.-Atmos., 108, 4783, https://doi.org/10.1029/2003JD003757, 2003.

Baars, H., Kanitz, T., Engelmann, R., Althausen, D., Heese, B., Komppula, M., Preißler, J., Tesche, M., Ansmann, A., Wandinger, U., Lim, J.-H., Ahn, J. Y., Stachlewska, I. S., Amiridis, V., Marinou, E., Seifert, P., Hofer, J., Skupin, A., Schneider, F., Bohlmann, S., Foth, A., Bley, S., Pfüller, A., Giannakaki, E., Lihavainen, H., Viisanen, Y., Hooda, R. K., Pereira, S. N., Bortoli, D., Wagner, F., Mattis, I., Janicka, L., Markowicz, K. M., Achtert, P., Artaxo, P., Pauliquevis, T., Souza, R. A. F., Sharma, V. P., van Zyl, P. G., Beukes, J. P., Sun, J., Rohwer, E. G., Deng, R., Mamouri, R.-E., and Zamorano, F.: An overview of the first decade of PollyNET: an emerging network of automated Raman-polarization lidars for continuous aerosol profiling, Atmos. Chem. Phys., 16, 5111-5137, https://doi.org/10.5194/acp16-5111-2016, 2016.

Baars, H., Seifert, P., Engelmann, R., and Wandinger, U.: Target categorization of aerosol and clouds by continuous multiwavelength-polarization lidar measurements, Atmos. Meas. Tech., 10, 3175-3201, https://doi.org/10.5194/amt-103175-2017, 2017.

Burton, S. P., Ferrare, R. A., Hostetler, C. A., Hair, J. W., Rogers, R. R., Obland, M. D., Butler, C. F., Cook, A. L., Harper, D. B., and
Froyd, K. D.: Aerosol classification using airborne High Spectral Resolution Lidar measurements - methodology and examples, Atmos. Meas. Tech., 5, 73-98, https://doi.org/10.5194/amt-5-732012, 2012.

Burton, S. P., Hair, J. W., Kahnert, M., Ferrare, R. A., Hostetler, C. A., Cook, A. L., Harper, D. B., Berkoff, T. A., Seaman, S. T., Collins, J. E., Fenn, M. A., and Rogers, R. R.: Observations of the spectral dependence of linear particle depolarization ratio of aerosols using NASA Langley airborne High Spectral Resolution Lidar, Atmos. Chem. Phys., 15, 13453-13473, https://doi.org/10.5194/acp-15-13453-2015, 2015.

Dubovik, O. and King, M. D.: A flexible inversion algorithm for retrieval of aerosol optical properties from Sun and sky radiance measurements, J. Geophys. Res.-Atmos., 105, 20673-20696, https://doi.org/10.1029/2000JD900282, 2000.

Dubovik, O., Sinyuk, A., Lapyonok, T., Holben, B. N., Mishchenko, M., Yang, P., Eck, T. F., Volten, H., Muñoz, O., Veihelmann, B., van der Zande, W. J., Leon, J.-F., Sorokin, M., and Slutsker, I.: Application of spheroid models to account for aerosol particle nonsphericity in remote sensing of desert dust, J. Geophys. Res.Atmos., 111, D11208, https://doi.org/10.1029/2005JD006619, 2006.

Dubovik, O., Lapyonok, T., Litvinov, P., Herman, M., Fuertes, D., Ducos, F., Lopatin, A., Chaikovsky, A., Torres, B., Derimian, Y., Huang, X., Aspetsberger, M., and Federspiel, C.: GRASP: a versatile algorithm for characterizing the atmosphere, SPIE: Newsroom, https://doi.org/10.1117/2.1201408.005558, 2014.

Dubovik, O., Fuertes, D., Litvinov, P., Lopatin, A., Lapyonok, T., Doubovik, I., Xu, F., Ducos, F., Chen, C., Torres, B., Derimian, Y., Li, L., Herreras-Giralda, M., Herrera, M., Karol, Y., Matar, C., Schuster, G. L., Espinosa, R., Puthukkudy, A., Li, Z., Fischer, J., Preusker, R., Cuesta, J., Kreuter, A., Cede, A., Aspetsberger, M., Marth, D., Bindreiter, L., Hangler, A., Lanzinger, V., Holter, C., and Federspiel, C.: A Comprehensive Description of MultiTerm LSM for Applying Multiple a Priori Constraints in Problems of Atmospheric Remote Sensing: GRASP Algorithm, Concept, and Applications, Frontiers in Remote Sensing, 2, 706851, https://doi.org/10.3389/frsen.2021.706851, 2021.

Engelmann, R., Kanitz, T., Baars, H., Heese, B., Althausen, D., Skupin, A., Wandinger, U., Komppula, M., Stachlewska, I. S., Amiridis, V., Marinou, E., Mattis, I., Linné, H., and Ansmann, A.: The automated multiwavelength Raman polarization and water-vapor lidar PollyXT: the neXT generation, Atmos. Meas. Tech., 9, 1767-1784, https://doi.org/10.5194/amt-9-1767-2016, 2016.

Engelmann, R., Ansmann, A., Ohneiser, K., Griesche, H., Radenz, M., Hofer, J., Althausen, D., Dahlke, S., Maturilli, M., Veselovskii, I., Jimenez, C., Wiesen, R., Baars, H., Bühl, J., Gebauer, H., Haarig, M., Seifert, P., Wandinger, U., and Macke, A.: Wildfire smoke, Arctic haze, and aerosol effects on mixedphase and cirrus clouds over the North Pole region during MOSAiC: an introduction, Atmos. Chem. Phys., 21, 13397-13423, https://doi.org/10.5194/acp-21-13397-2021, 2021.

Freudenthaler, V.: About the effects of polarising optics on lidar signals and the $\Delta 90$ calibration, Atmos. Meas. Tech., 9, 41814255, https://doi.org/10.5194/amt-9-4181-2016, 2016.

Freudenthaler, V., Esselborn, M., Wiegner, M., Heese, B., Tesche, M., Ansmann, A., Müller, D., Althausen, D., Wirth, M., Fix, A., Ehret, G., Knippertz, P., Toledano, C., Gasteiger, J., Garham- 
mer, M., and Seefeldner, M.: Depolarization ratio profiling at several wavelengths in pure Saharan dust during SAMUM 2006, Tellus B, 61, 165-179, https://doi.org/10.1111/j.16000889.2008.00396.x, 2009.

Gasteiger, J., Wiegner, M., Groß, S., Freudenthaler, V., Toledano, C., Tesche, M., and Kandler, K.: Modelling lidar-relevant optical properties of complex mineral dust aerosols, Tellus B, 63, 725741, https://doi.org/10.1111/j.1600-0889.2011.00559.x, 2011.

Giles, D. M., Sinyuk, A., Sorokin, M. G., Schafer, J. S., Smirnov, A., Slutsker, I., Eck, T. F., Holben, B. N., Lewis, J. R., Campbell, J. R., Welton, E. J., Korkin, S. V., and Lyapustin, A. I.: Advancements in the Aerosol Robotic Network (AERONET) Version 3 database - automated near-real-time quality control algorithm with improved cloud screening for Sun photometer aerosol optical depth (AOD) measurements, Atmos. Meas. Tech., 12, 169209, https://doi.org/10.5194/amt-12-169-2019, 2019.

Groß, S., Esselborn, M., Weinzierl, B., Wirth, M., Fix, A., and Petzold, A.: Aerosol classification by airborne high spectral resolution lidar observations, Atmos. Chem. Phys., 13, 2487-2505, https://doi.org/10.5194/acp-13-2487-2013, 2013.

Groß, S., Freudenthaler, V., Schepanski, K., Toledano, C., Schäfler, A., Ansmann, A., and Weinzierl, B.: Optical properties of long-range transported Saharan dust over Barbados as measured by dual-wavelength depolarization Raman lidar measurements, Atmos. Chem. Phys., 15, 11067-11080, https://doi.org/10.5194/acp-15-11067-2015, 2015.

Haarig, M., Engelmann, R., Ansmann, A., Veselovskii, I., Whiteman, D. N., and Althausen, D.: $1064 \mathrm{~nm}$ rotational Raman lidar for particle extinction and lidar-ratio profiling: cirrus case study, Atmos. Meas. Tech., 9, 4269-4278, https://doi.org/10.5194/amt9-4269-2016, 2016.

Haarig, M., Ansmann, A., Althausen, D., Klepel, A., Groß, S., Freudenthaler, V., Toledano, C., Mamouri, R.-E., Farrell, D. A., Prescod, D. A., Marinou, E., Burton, S. P., Gasteiger, J., Engelmann, R., and Baars, H.: Triple-wavelength depolarizationratio profiling of Saharan dust over Barbados during SALTRACE in 2013 and 2014, Atmos. Chem. Phys., 17, 10767-10794, https://doi.org/10.5194/acp-17-10767-2017, 2017.

Haarig, M., Ansmann, A., Baars, H., Jimenez, C., Veselovskii, I., Engelmann, R., and Althausen, D.: Depolarization and lidar ratios at 355, 532, and $1064 \mathrm{~nm}$ and microphysical properties of aged tropospheric and stratospheric Canadian wildfire smoke, Atmos. Chem. Phys., 18, 11847-11861, https://doi.org/10.5194/acp-18-11847-2018, 2018.

Hofer, J., Ansmann, A., Althausen, D., Engelmann, R., Baars, H., Fomba, K. W., Wandinger, U., Abdullaev, S. F., and Makhmudov, A. N.: Optical properties of Central Asian aerosol relevant for spaceborne lidar applications and aerosol typing at 355 and $532 \mathrm{~nm}$, Atmos. Chem. Phys., 20, 9265-9280, https://doi.org/10.5194/acp-20-9265-2020, 2020.

Holben, B., Eck, T., Slutsker, I., Tanré, D., Buis, J., Setzer, A., Vermote, E., Reagan, J., Kaufman, Y., Nakajima, T., Lavenu, F., Jankowiak, I., and Smirnov, A.: AERONET-A Federated Instrument Network and Data Archive for Aerosol Characterization, Remote Sens. Environ., 66, 1-16, https://doi.org/10.1016/S0034-4257(98)00031-5, 1998.

Hu, Q., Wang, H., Goloub, P., Li, Z., Veselovskii, I., Podvin, T., Li, K., and Korenskiy, M.: The characterization of Taklamakan dust properties using a multiwavelength Raman polarization lidar in Kashi, China, Atmos. Chem. Phys., 20, 13817-13834, https://doi.org/10.5194/acp-20-13817-2020, 2020.

Jimenez, C., Ansmann, A., Engelmann, R., Donovan, D., Malinka, A., Schmidt, J., Seifert, P., and Wandinger, U.: The dual-field-of-view polarization lidar technique: a new concept in monitoring aerosol effects in liquid-water clouds - theoretical framework, Atmos. Chem. Phys., 20, 15247-15263, https://doi.org/10.5194/acp-20-15247-2020, 2020.

Kemppinen, O., Nousiainen, T., and Lindqvist, H.: The impact of surface roughness on scattering by realistically shaped wavelength-scale dust particles, J. Quant. Spectrosc. Ra., 150, 55-67, https://doi.org/10.1016/j.jqsrt.2014.05.024, 2015.

Kim, M.-H., Omar, A. H., Tackett, J. L., Vaughan, M. A., Winker, D. M., Trepte, C. R., Hu, Y., Liu, Z., Poole, L. R., Pitts, M. C., Kar, J., and Magill, B. E.: The CALIPSO version 4 automated aerosol classification and lidar ratio selection algorithm, Atmos. Meas. Tech., 11, 6107-6135, https://doi.org/10.5194/amt11-6107-2018, 2018.

Liu, Z., Omar, A., Vaughan, M., Hair, J., Kittaka, C., Hu, Y., Powell, K., Trepte, C., Winker, D., Hostetler, C., Ferrare, R., and Pierce, R.: CALIPSO lidar observations of the optical properties of Saharan dust: A case study of long-range transport, J. Geophys. Res.-Atmos., 113, d07207, https://doi.org/10.1029/2007JD008878, 2008.

Lopatin, A., Dubovik, O., Fuertes, D., Stenchikov, G., Lapyonok, T., Veselovskii, I., Wienhold, F. G., Shevchenko, I., Hu, Q., and Parajuli, S.: Synergy processing of diverse ground-based remote sensing and in situ data using the GRASP algorithm: applications to radiometer, lidar and radiosonde observations, Atmos. Meas. Tech., 14, 2575-2614, https://doi.org/10.5194/amt14-2575-2021, 2021.

Mamouri, R.-E. and Ansmann, A.: Potential of polarization/Raman lidar to separate fine dust, coarse dust, maritime, and anthropogenic aerosol profiles, Atmos. Meas. Tech., 10, 3403-3427, https://doi.org/10.5194/amt-10-3403-2017, 2017.

Mattis, I., Ansmann, A., Müller, D., Wandinger, U., and Althausen, D.: Dual-wavelength Raman lidar observations of the extinctionto-backscatter ratio of Saharan dust, Geophys. Res. Lett., 29, 201-20-4, https://doi.org/10.1029/2002GL014721, 2002.

Miffre, A., Mehri, T., Francis, M., and Rairoux, P.: UV-VIS depolarization from Arizona Test Dust particles at exact backscattering angle, J. Quant. Spectrosc. Ra., 169, 79-90, https://doi.org/10.1016/j.jqsrt.2015.09.016, 2016.

Müller, D., Ansmann, A., Freudenthaler, V., Kandler, K., Toledano, C., Hiebsch, A., Gasteiger, J., Esselborn, M., Tesche, M., Heese, B., Althausen, D., Weinzierl, B., Petzold, A., and von Hoyningen-Huene, W.: Mineral dust observed with AERONET Sun photometer, Raman lidar, and in situ instruments during SAMUM 2006: Shape-dependent particle properties, J. Geophys. Res.-Atmos., 115, D11207, https://doi.org/10.1029/2009JD012523, 2010.

Müller, D., Lee, K.-H., Gasteiger, J., Tesche, M., Weinzierl, B., Kandler, K., Müller, T., Toledano, C., Otto, S., Althausen, D., and Ansmann, A.: Comparison of optical and microphysical properties of pure Saharan mineral dust observed with AERONET Sun photometer, Raman lidar, and in situ instruments during SAMUM 2006, J. Geophys. Res.-Atmos., 117, D07211, https://doi.org/10.1029/2011JD016825, 2012. 
Noh, Y., Müller, D., Lee, K., Kim, K., Lee, K., Shimizu, A., Sano, I., and Park, C. B.: Depolarization ratios retrieved by AERONET sun-sky radiometer data and comparison to depolarization ratios measured with lidar, Atmos. Chem. Phys., 17, 6271-6290, https://doi.org/10.5194/acp-17-6271-2017, 2017.

Omar, A. H., Winker, D. M., Vaughan, M. A., Hu, Y., Trepte, C. R., Ferrare, R. A., Lee, K.-P., Hostetler, C. A., Kittaka, C., Rogers, R. R., Kuehn, R. E., and Liu, Z.: The CALIPSO Automated Aerosol Classification and Lidar Ratio Selection Algorithm, J. Atmos. Ocean. Tech., 26, 1994-2014, https://doi.org/10.1175/2009JTECHA1231.1, 2009.

Ortiz-Amezcua, P., Bedoya-Velásquez, A. E., Benavent-Oltra, J. A., Pérez-Ramírez, D., Veselovskii, I., Castro-Santiago, M., BravoAranda, J. A., Guedes, A., Guerrero-Rascado, J. L., and AladosArboledas, L.: Implementation of UV rotational Raman channel to improve aerosol retrievals from multiwavelength lidar, Opt. Express, 28, 8156-8168, https://doi.org/10.1364/OE.383441, 2020.

Pappalardo, G., Amodeo, A., Apituley, A., Comeron, A., Freudenthaler, V., Linné, H., Ansmann, A., Bösenberg, J., D’Amico, G., Mattis, I., Mona, L., Wandinger, U., Amiridis, V., AladosArboledas, L., Nicolae, D., and Wiegner, M.: EARLINET: towards an advanced sustainable European aerosol lidar network, Atmos. Meas. Tech., 7, 2389-2409, https://doi.org/10.5194/amt7-2389-2014, 2014.

PollyNET: Worldwide observations with the portable Raman lidar systems (Polly), available at: https://polly.tropos.de/ (last access: 20 October 2021.

Radenz, M., Seifert, P., Baars, H., Floutsi, A. A., Yin, Z., and Bühl, J.: Automated time-height-resolved air mass source attribution for profiling remote sensing applications, Atmos. Chem. Phys., 21, 3015-3033, https://doi.org/10.5194/acp-213015-2021, 2021.

Saito, M. and Yang, P.: and Advanced Bulk Optical Models Linking the Backscattering and Microphysical Properties of Mineral Dust Aerosol, Geophys. Res. Lett., 48, e2021GL095121, https://doi.org/10.1029/2021GL095121, 2021.

Saito, M., Yang, P., Ding, J., and Liu, X.: A Comprehensive Database of the Optical Properties of Irregular Aerosol Particles for Radiative Transfer Simulations, J. Atmos. Sci., 78, 20892111, 2021.

Schuster, G. L., Vaughan, M., MacDonnell, D., Su, W., Winker, D., Dubovik, O., Lapyonok, T., and Trepte, C.: Comparison of CALIPSO aerosol optical depth retrievals to AERONET measurements, and a climatology for the lidar ratio of dust, Atmos. Chem. Phys., 12, 7431-7452, https://doi.org/10.5194/acp12-7431-2012, 2012.

Shin, S.-K., Tesche, M., Kim, K., Kezoudi, M., Tatarov, B., Müller, D., and Noh, Y.: On the spectral depolarisation and lidar ratio of mineral dust provided in the AERONET version 3 inversion product, Atmos. Chem. Phys., 18, 12735-12746, https://doi.org/10.5194/acp-18-12735-2018, 2018.

Sinyuk, A., Holben, B. N., Eck, T. F., Giles, D. M., Slutsker, I., Korkin, S., Schafer, J. S., Smirnov, A., Sorokin, M., and Lyapustin, A.: The AERONET Version 3 aerosol retrieval algorithm, associated uncertainties and comparisons to Version 2, Atmos. Meas. Tech., 13, 3375-3411, https://doi.org/10.5194/amt13-3375-2020, 2020.
Stein, A. F., Draxler, R. R., Rolph, G. D., Stunder, B. J. B., Cohen, M. D., and Ngan, F.: NOAA's HYSPLIT Atmospheric Transport and Dispersion Modeling System, B. Am. Meteorol. Soc., 96, 2059-2077, https://doi.org/10.1175/BAMS-D-14$00110.1,2015$.

Tesche, M., Ansmann, A., Müller, D., Althausen, D., Mattis, I., Heese, B., Freudenthaler, V., Wiegner, M., Esselborn, M., Pisani, G., and Knippertz, P.: Vertical profiling of Saharan dust with Raman lidars and airborne HSRL in southern Morocco during SAMUM, Tellus B, 61, 144-164, https://doi.org/10.1111/j.16000889.2008.00390.x, 2009.

Tesche, M., Groß, S., Ansmann, A., Müller, D., Althausen, D., Freudenthaler, V., and Esselborn, M.: Profiling of Saharan dust and biomass-burning smoke with multiwavelength polarization Raman lidar at Cape Verde, Tellus B, 63, 649-676, https://doi.org/10.1111/j.1600-0889.2011.00548.x, 2011.

Toledano, C., Torres, B., Velasco-Merino, C., Althausen, D., Groß, S., Wiegner, M., Weinzierl, B., Gasteiger, J., Ansmann, A., González, R., Mateos, D., Farrel, D., Müller, T., Haarig, M., and Cachorro, V. E.: Sun photometer retrievals of Saharan dust properties over Barbados during SALTRACE, Atmos. Chem. Phys., 19, 14571-14583, https://doi.org/10.5194/acp-19-145712019, 2019.

Torres, B., Dubovik, O., Fuertes, D., Schuster, G., Cachorro, V. E., Lapyonok, T., Goloub, P., Blarel, L., Barreto, A., Mallet, M., Toledano, C., and Tanré, D.: Advanced characterisation of aerosol size properties from measurements of spectral optical depth using the GRASP algorithm, Atmos. Meas. Tech., 10, 3743-3781, https://doi.org/10.5194/amt-10-3743-2017, 2017.

Vaughan, M. A., Liu, Z., McGill, M. J., Hu, Y., and Obland, M. D.: On the spectral dependence of backscatter from cirrus clouds: Assessing CALIOP's 1064 nm calibration assumptions using cloud physics lidar measurements, J. Geophys. Res.-Atmos., 115, D14206, https://doi.org/10.1029/2009JD013086, 2010.

Veselovskii, I., Whiteman, D. N., Korenskiy, M., Suvorina, A., and Pérez-Ramírez, D.: Use of rotational Raman measurements in multiwavelength aerosol lidar for evaluation of particle backscattering and extinction, Atmos. Meas. Tech., 8, 41114122, https://doi.org/10.5194/amt-8-4111-2015, 2015.

Veselovskii, I., Goloub, P., Podvin, T., Bovchaliuk, V., Derimian, Y., Augustin, P., Fourmentin, M., Tanre, D., Korenskiy, M., Whiteman, D. N., Diallo, A., Ndiaye, T., Kolgotin, A., and Dubovik, O.: Retrieval of optical and physical properties of African dust from multiwavelength Raman lidar measurements during the SHADOW campaign in Senegal, Atmos. Chem. Phys., 16, 70137028, https://doi.org/10.5194/acp-16-7013-2016, 2016.

Veselovskii, I., Hu, Q., Goloub, P., Podvin, T., Korenskiy, M., Derimian, Y., Legrand, M., and Castellanos, P.: Variability in lidarderived particle properties over West Africa due to changes in absorption: towards an understanding, Atmos. Chem. Phys., 20, 6563-6581, https://doi.org/10.5194/acp-20-6563-2020, 2020.

Weinzierl, B., Ansmann, A., Prospero, J. M., Althausen, D., Benker, N., Chouza, F., Dollner, M., Farrell, D., Fomba, W. K., Freudenthaler, V., Gasteiger, J., Groß, S., Haarig, M., Heinold, B., Kandler, K., Kristensen, T. B., Mayol-Bracero, O. L., Müller, T., Reitebuch, O., Sauer, D., Schäfler, A., Schepanski, K., Spanu, A., Tegen, I., Toledano, C., and Walser, A.: The Saharan Aerosol Long-range Transport and Aerosol-Cloud-Interaction Experiment (SALTRACE): overview and selected highlights, B. Am. 
Meteorol. Soc., 98, 1427-1451, https://doi.org/10.1175/BAMSD-15-00142.1, 2017.

Whiteman, D. N.: Examination of the traditional Raman lidar technique. I. Evaluating the temperaturedependent lidar equations, Appl. Optics, 42, 2571-2592, https://doi.org/10.1364/AO.42.002571, 2003a.
Whiteman, D. N.: Examination of the traditional Raman lidar technique. II. Evaluating the ratios for water vapor and aerosols, Appl. Optics, 42, 2593-2608, https://doi.org/10.1364/AO.42.002593, 2003b.

Yorks, J. E., McGill, M. J., Palm, S. P., Hlavka, D. L., Selmer, P. A., Nowottnick, E. P., Vaughan, M. A., Rodier, S. D., and Hart, W. D.: An overview of the CATS level 1 processing algorithms and data products, Geophys. Res. Lett., 43, 4632-4639, https://doi.org/10.1002/2016GL068006, 2016. 